\title{
Lariatins, Novel Anti-mycobacterial Peptides with a Lasso Structure, Produced by Rhodococcus jostii K01-B0171
}

\author{
Masato Iwatsuki, Ryuji Uchida, Yoichi Takakusagi, Atsuko Matsumoto, \\ Cheng-Lin Jiang, Yoko Takahashi, Masayoshi Arai, Susumu Kobayashi, \\ Makoto Matsumoto, Junji Inokoshi, Hiroshi Tomoda, Satoshi Ōmura
}

Received: March 8, 2007 / Accepted: May 23, 2007

(C) Japan Antibiotics Research Association

\begin{abstract}
Two anti-mycobacterial peptides with a lasso structure, named lariatins A and B, were separated by HP20 and ODS column chromatographies and purified by HPLC from the culture broth of Rhodococcus jostii K01B0171, which was isolated from soil aggregates collected in Yunnan, China. Lariains A and B showed growth inhibition against Mycobacterium smegmatis with MIC values of 3.13 and $6.25 \mu \mathrm{g} / \mathrm{ml}$ in agar dilution method, respectively. Furthermore, lariatin A inhibited the growth of Mycobacterium tuberculosis with an MIC of $0.39 \mu \mathrm{g} / \mathrm{ml}$ in liquid microdilution method.
\end{abstract}

Keywords lariatin A, lariatin B, lasso structure, antimycobacterial peptide, tuberculosis, Rhodococcus jostii, soil aggregates

\section{Introduction}

Our research group has focused on discovery of antiinfectives from microbial metabolites [1 3]. Tuberculosis (TB) is still the greatest single infectious cause of mortality in the world, together with HIV and malaria [4]. Moreover,

H. Tomoda (Corresponding author), R. Uchida, J. Inokoshi: School of Pharmacy, Kitasato University, 5-9-1 Shirokane, Minato-ku, Tokyo 108-8641, Japan,

E-mail: tomodah@pharm.kitasato-u.ac.jp

Y. Takahashi, M. Arai, S. Ōmura: Kitasato Insutitute for Life Sciences, Kitasato University, 5-9-1 Shirokane, Minato-ku, Tokyo 108-8641, Japan

M. Iwatsuki, A. Matsumoto, S. Ōmura: The Kitasato Institute, 5-9-1 Shirokane, Minato-ku, Tokyo 108-8642, Japan the spread of the HIV promoted to increase the number of tuberculosis patients [5]. However, powerful anti-TB drugs with a new mechanism of action have not been developed in last over thirty years, and only 5 anti-TB drugs can be clinically used still now. Since isoniazid and ethambutol, first-line anti-TB drugs, show specific inhibition against Mycobacteria, we have screened for new agents from microbial metabolites having specific inhibition against Mycobacterium smegmatis among 16 test microorganisms including Gram-positive and -negative bacteria, fungi and yeasts. As a part of this program, we discovered novel

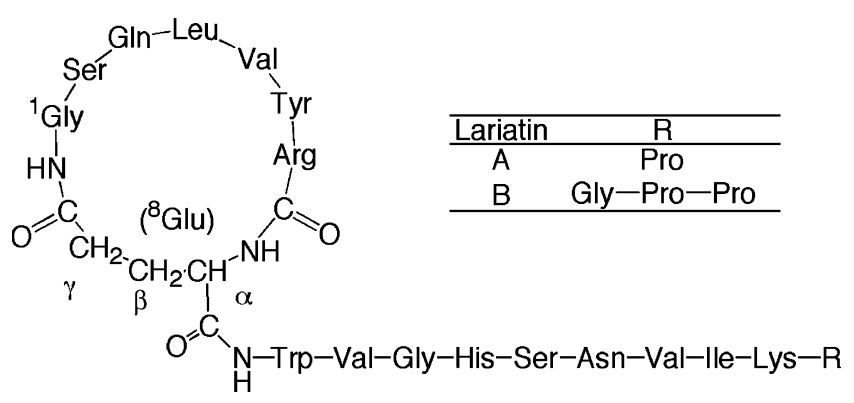

Fig. 1 Structures of lariatins A and B.

C.-L. Jiang: Yunnan Institute of Microbiology, Yunnan University, Kunming, Yunnan 650091, China

Y. Takakusagi, S. Kobayashi: Faculty of Pharmaceutical Sciences, Science University of Tokyo, 2641 Yamazaki, Noda-shi, Chiba 278-8510, Japan

M. Matsumoto: Microbiological Research Institute Otsuka Pharmaceutical Co., Ltd., 463-10 Kagasuno, Kawauchi-cho, Tokushima 771-0192, Japan 


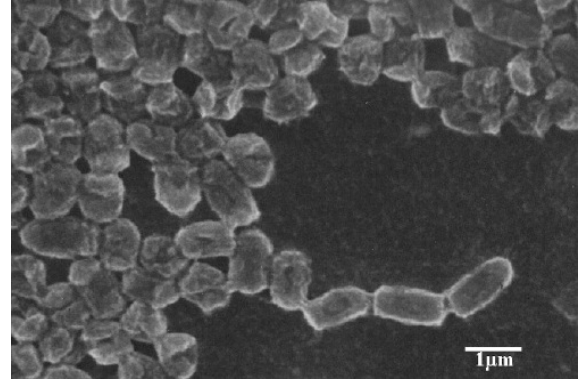

Fig. 2 Scanning electron micrograph of Rhodococcus jostii K01-B0171.

compounds designated lariatins A and B (Fig. 1), unique cyclic peptides produced by Rhodococcus jostii K01B0171 (Fig. 2). These peptides consist of 18 and 20 amino acid residues with an internal linkage between the $\gamma$ carboxyl group of Glu8 and the $\alpha$-amino group of Gly1, and the tail region passes through the ring region. (Fig. 3). The structure elucidation was published elsewhere [6]. In this paper, the taxonomy, fermenation, isolation and physico-chemical and biological properties of lariatins are described. Lariatin A showed growth inhibition against not only M. smegmatis but also Mycobacterium tuberculosis.

\section{Materials and Methods}

\section{Isolation of Strain K01-B0171}

Soil was collected in Yunnan, China. Isolation method of strain K01-B0171 from soil aggregates was reported in detail elsewhere [7]. In brief, soil aggregates with diameters of $160 \sim 990 \mu \mathrm{m}$ were collected by using filters, and washed with acidic electrolyzed water and sterilized water. The aggregates suspended in sterilized water were then disrupted by a sonicater, and the mixture were spread on Waksman plates to isolate colonies of microorganisms.

\section{Taxonomic Studies}

The cultural and physiological characteristics of the strain were determined following the methods recommended by the International Streptomyces Project (ISP [8]) and Waksman [9]. The utilization of carbon sources was tested by growth on Pridham and Gottlieb's medium containing $1.0 \%$ carbon at $27^{\circ} \mathrm{C}[10]$. The morphological properties were observed with a scanning electron microscope (model JSM-5600, JEOL). Isomers of diaminopimelic acid (DAP) in whole-cell hydrolysates were determined by the standard methods using TLC $[11,12]$, and the $N$-acyl types of muramic acid were determined by the method of Uchida and Aida [13]. Whole-cell sugars were analyzed

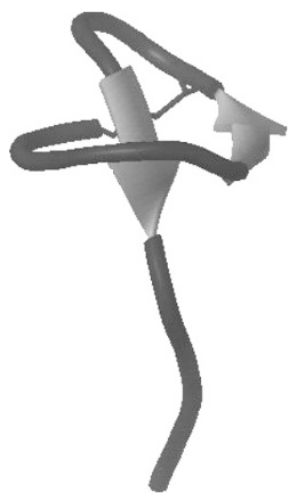

Fig. 3 Lasso structure of lariatin A.

[11], presence of mycolic acids was examined by the TLC method [14], and phospholipids were extracted and identified by the method of Minnikin et al. [15]. Menaquinones were extracted and purified by the method of Collins et al. [16], then analyzed by HPLC (model 802-SC, JASCO) on a chromatograph equipped with a CAPCELL PAK C18 column (Shiseido Co.) [17]. The $\mathrm{G}+\mathrm{C}$ content $(\mathrm{mol} \%)$ of chromosomal DNA was determined by the HPLC method of Tamaoka and Komagata [18]. 16S rDNA was amplified by PCR and was sequenced directly on an ABI model 377A automatic DNA sequencer using a PRISM Ready Reaction Dye Primer Cycle Sequencing Kit (Applied Biosystems). The CLUSTAL W software package (Thompson et al. [19]) was used for multiple-alignment with selected sequences for calculating evolutionary distances (Kimura [20]) and similarity values and for constructing a phylogenetic tree based on the neighbor-joining method (Saitou et al. [21]).

\section{Analysis of Lariatin Production by HPLC}

The production of lariatins was measured by analytical HPLC under the following conditions: column, Symmetry C18 (2.1 $\times 150 \mathrm{~mm}$, Waters Co.); mobile phase, acetonitrile water with $0.05 \%$ phosphoric acid, $0 \sim 40 \%$ (20 minutes); UV detection at $210 \mathrm{~nm}$; flow rate of $0.2 \mathrm{ml} /$ minute. Lariatins A and B were eluted with retention times of 12.3 and 12.5 minutes, respectively.

\section{General Procedures}

The mass spectra were measured with a JOEL JSM-700 MS station and a JOEL JSM-AX 505 HA in thioglycerol. IR spectra were run in $\mathrm{KBr}$ on a HORIBA FT-210. The UV spectra were recorded on a HITACHI 340. The optical rotations were measured on a JASCO DIP-1000 Digital Polarimeter with a $5 \mathrm{~cm}$ cell. The melting points were measured on a Yanagimoto Micro Melting Point Apparatus MP-S3. 


\section{Assay for Antimicrobial Activities}

Antimicrobial activity was measured by paper disk method (6 mm, ADVANTEC) containing a test sample [22]. The culture conditions were followed; Bacillus subtilis ATCC6633 [Davis synthetic medium $(0.7 \%$ $\mathrm{K}_{2} \mathrm{HPO}_{4}, \quad 0.2 \% \quad \mathrm{KH}_{2} \mathrm{PO}_{4}, 0.5 \%$ sodium citrate, $0.1 \%$ ammonium sulfate, $0.2 \%$ glucose, $0.01 \% \mathrm{MgSO}_{4} \cdot 7 \mathrm{H}_{2} \mathrm{O}$ and $0.8 \%$ agar), $1.0 \%$ inoculation, $37^{\circ} \mathrm{C}, 24$ hours], Staphylococcus aureus ATCC6538P [Nutrient agar $(0.5 \%$ peptone, $0.5 \%$ meat extract and $0.8 \%$ agar), $0.2 \%$ inoculation, $37^{\circ} \mathrm{C}, 24$ hours], Micrococcus luteus ATCC9341 [Nutrient agar, $0.2 \%$ inoculation, $37^{\circ} \mathrm{C}, 24$ hours], Mycobacterium smegmatis ATCC607 [Waksman agar $(0.5 \%$ peptone, $0.5 \%$ meat extract, $0.3 \% \mathrm{NaCl}, 1.0 \%$ glucose and $0.8 \%$ agar), $1.0 \%$ inoculation, $37^{\circ} \mathrm{C}, 24$ hours], Escherichia coli NIHJ [Nutrient agar, $0.5 \%$ inoculation, $37^{\circ} \mathrm{C}, 24$ hours], Pseudomonas aeruginosa IFO3080 [Nutrien agar, $1.9 \%$ inoculation, $37^{\circ} \mathrm{C}, 24$ hours], Xanthomonas camestris KB88 [Nutrient agar, 1.0\% inoculation, $37^{\circ} \mathrm{C}, 24$ hours], Bacteroides fragilis ATCC23745 [GAM medium (5.0\% GAM broth and 1.5\% agar), $2.0 \%$ inoculation, $37^{\circ} \mathrm{C}, 24$ hours], Acholeplasma laidlawii KB174 [Ala medium (3.0\% PPLO broth, $0.2 \%$ phenol red $(5.0 \mathrm{mg} / \mathrm{ml}), 0.1 \%$ glucose, $1.5 \%$ agar, $15.0 \%$ Horse serum and $1.0 \%$ penicillin G), 20\% inoculation, $37^{\circ} \mathrm{C}, 24$ hours], Pyricularia orizae KF180 [GY agar (1.0\% glucose, $0.5 \%$ yeast extract and $0.8 \%$ agar adjusted in $\mathrm{pH} 6.0,2.0 \%$ inoculation, $37^{\circ} \mathrm{C}, 24$ hours), Aspergillus niger ATCC9642 [GY agar, 0.3\% inoculation, $27^{\circ} \mathrm{C}, 48$ hours], Mucor racemosus IFO4581 [GY agar, $0.3 \%$ inoculation, $27^{\circ} \mathrm{C}, 48$ hours], Candida albicans ATCC64548 [GY agar, $0.2 \%$ inoculation, $27^{\circ} \mathrm{C}, 24$ hours] and Saccharomyces cerevisiae KF26 [GY agar, 0.3\% inoculation, $27^{\circ} \mathrm{C}, 24$ hours].

Anti-mycobacterial activity was measured by agar dilution method or liquid microdilution method. Agar dilution method: Test organisms were adjusted to approximately $1.0 \times 10^{6} \mathrm{CFU} / \mathrm{ml}$, and inoculated using multipoint inoculator (Sakuma). Middlebrook 7H11 agar plates with or without the test compounds were inoculated with the test organisms and incubated for 14 days at $37^{\circ} \mathrm{C}$ and then examined to determine the MIC for each organism.

Liquid microdilution method: M. tuberculosis H37Rv was adjusted to approximately $1.0 \times 10^{6} \mathrm{CFU} / \mathrm{ml}$ in Middlebrook $7 \mathrm{H} 9$ broth containing $0.05 \%$ Tween 80 and $0.5 \%$ glycerol. The culture broth $(200 \mu \mathrm{l})$ was added to each well of a 96-well microplate (Corning) with or without the test compounds. After incubation for 5 days at $37^{\circ} \mathrm{C}, 12.5 \%$ Tween $80(20 \mu \mathrm{l})$ and alamarblue $(20 \mu 1$, Biosource) were added to each well. After overnight incubation at $37^{\circ} \mathrm{C}$, the measurement of $\mathrm{A}_{570}$ and $\mathrm{A}_{600}$ was carried out to determine the MIC.

\section{Results}

\section{Taxonomy of the Producing Strain K01-B0171}

Strain K01-B0171 was isolated from a soil sample collected in Yunnan Province, China using the ultrasonic processor from the inside of soil aggregates [7]. Good growth occurred on yeast extract-malt extract agar, tyrosine agar, nutrient agar and others, and no aerial mycelia grew. Color of colonies was orange to brown. Cells were short rods or coccus and were $1.1 \sim 1.4 \times 0.7 \sim 0.8 \mu \mathrm{m}$ in size (Fig. 2). Growth temperature range was $6^{\circ} \mathrm{C}$ to $37^{\circ} \mathrm{C}$. D-Glucose, D-mannitol, D-fructose, L-rhamnose, myoinositol and sucrose were used but L-arabinose, raffinose, melibiose, and xylose were not used as sole carbon. No melanoid pigment was produced.

Strain K01-B0171 contained meso-DAP, arabinose and galactose in whole-cell hydrolysates. The acyl type of the peptidoglycan was glycolyl. The predominant menaquinone was MK-8 $\left(\mathrm{H}_{2}\right)$. Mycolic acids were detected and phosphatidylethanolamine was detected as the phospholipid. The $\mathrm{G}+\mathrm{C}$ content (mol\%) of the DNA was $66 \%$. These results indicated strain K01-B0171 belongs to the genus Rhodococcus. 16S rDNA sequence (1513 nucleotides) was determined for strain K01-B0171 and the DDBJ accession number is AB204817. The phylogenetic analysis with $16 \mathrm{~S}$ rDNA database sequences revealed that strain K01-B0171 branched deeply within a member of the genus Rhodococcus and most closely related to Rhodococcus jostii IFO $16295^{\mathrm{T}}$ [24] (Fig. 4). As the sequence similarity was high value $(99.5 \%)$, the strain K01B0171 should be identified with Rhodococcus jostii.

\section{Fermentation}

Strain K01-B0171 was grown and maintained on an agar slant consisting $1.0 \%$ starch, $0.3 \% \mathrm{NZ}$ amine, $0.1 \%$ yeast extract, $0.1 \%$ meat extract, $1.2 \%$ agar and $0.3 \% \mathrm{CaCO}_{3}$. For all liquid cultures, a medium was used consisting of $3.0 \%$ mannitol. $1.0 \%$ glucose, $0.5 \%$ yeast extract, $0.5 \%$ ammonium succinate, $0.1 \% \mathrm{KH}_{2} \mathrm{PO}_{4}, 0.1 \% \mathrm{MgSO}_{4} \cdot 7 \mathrm{H}_{2} \mathrm{O}$, $0.0001 \% \mathrm{FeSO}_{4} \cdot 7 \mathrm{H}_{2} \mathrm{O}, 0.0001 \% \mathrm{MgCl}_{2} \cdot 4 \mathrm{H}_{2} \mathrm{O}, 0.0001 \%$ $\mathrm{ZnSO}_{4} \cdot 7 \mathrm{H}_{2} \mathrm{O}, \quad 0.0001 \% \quad \mathrm{CuSO}_{4} \cdot 5 \mathrm{H}_{2} \mathrm{O}$ and $0.0001 \%$ $\mathrm{CoCl}_{2} \cdot 6 \mathrm{H}_{2} \mathrm{O}$ (pH 7.0 before sterilization). A loopful of spores of Rhodococcus sp. was inoculated into $200 \mathrm{ml}$ of medium in two 500-ml Erlenmeyer flasks on a rotary shaker $(210 \mathrm{rpm})$. The inoculated flasks were incubated at $27^{\circ} \mathrm{C}$ for 3 days. A $200 \mathrm{ml}$ portion of the culture was transferred to a 30-liter jar fermenter containing 20 liters of the same medium and the fermentation was carried out at 


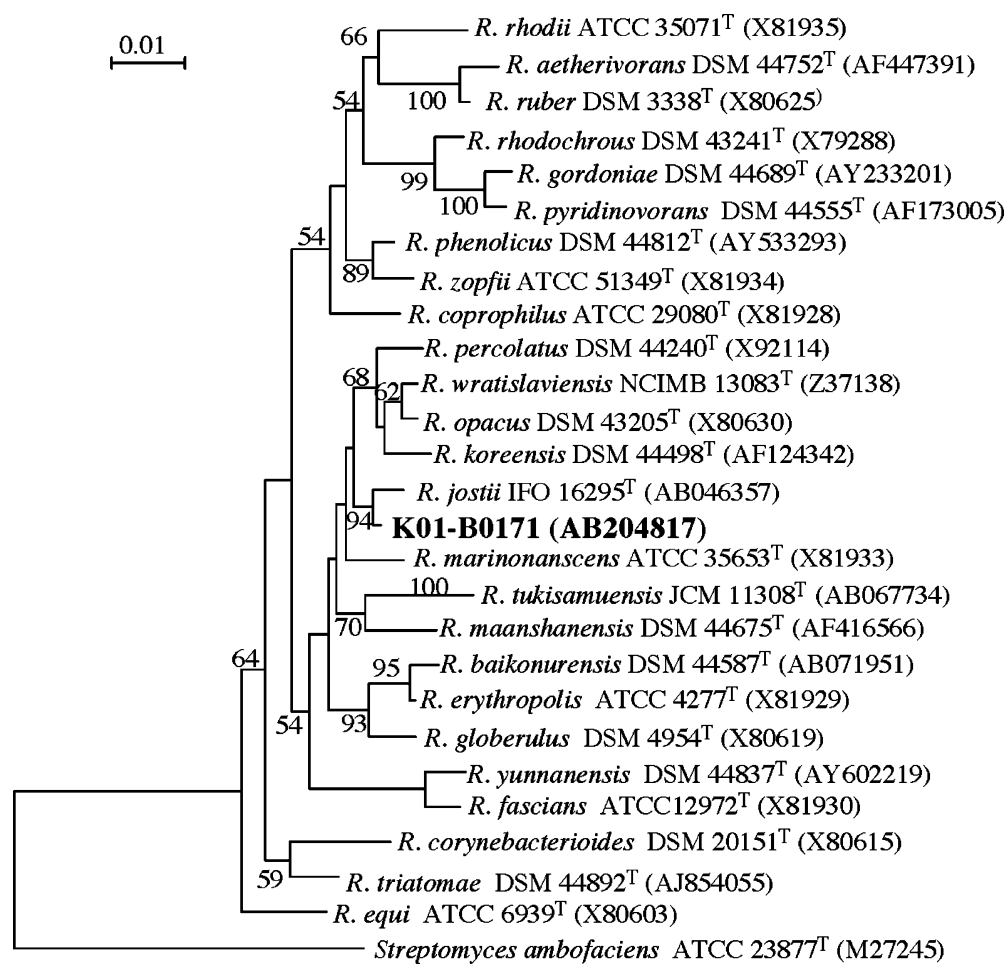

Fig. 4 Phylogenetic tree showing the position of strain K01-B0171 based on 16S rDNA analysis.

The numbers at the nodes indicate the level (\%) of bootstrap support based on neighbor-joining analysis of 1000 resampled date sets. Only value grater than $50 \%$ are shown.

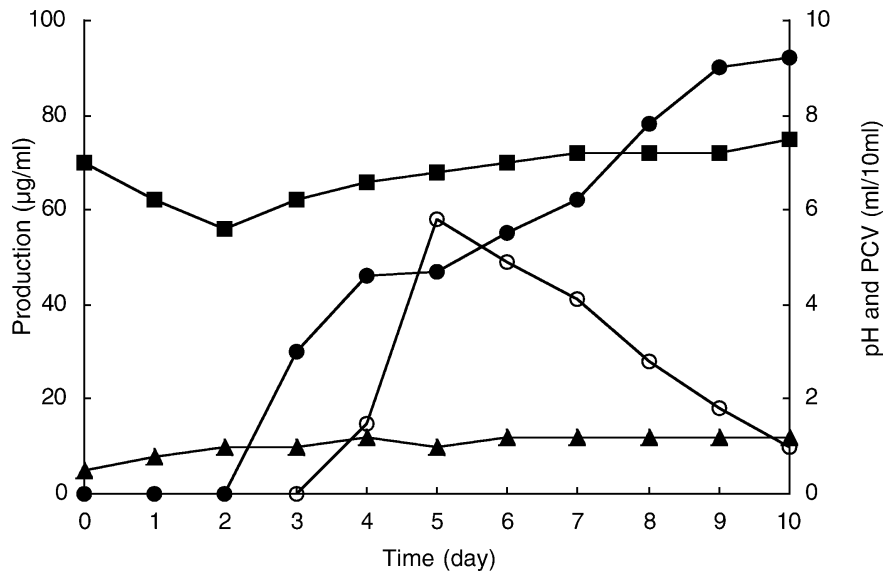

Fig. 5 Typical time course of lariatin production by Rhodococcus jostii K01-B0171.

PCV: $\boldsymbol{\Lambda}, \mathrm{pH}: \mathbf{\square}$, lariatin $\mathrm{A}: \bullet$ and lariatin $\mathrm{B}: \mathrm{O}$.

$37^{\circ} \mathrm{C}$ for 4 days. The typical time course of fermentation is shown in Fig. 5. The production of lariatin A was slowly increased and reached a maximum level of about $90 \mu \mathrm{g} / \mathrm{ml}$ on day 10 after inoculation. The production of lariatin B reached a maximum level of about $60 \mu \mathrm{g} / \mathrm{ml}$ on day 5 , thereafter the amount slowly decreased.

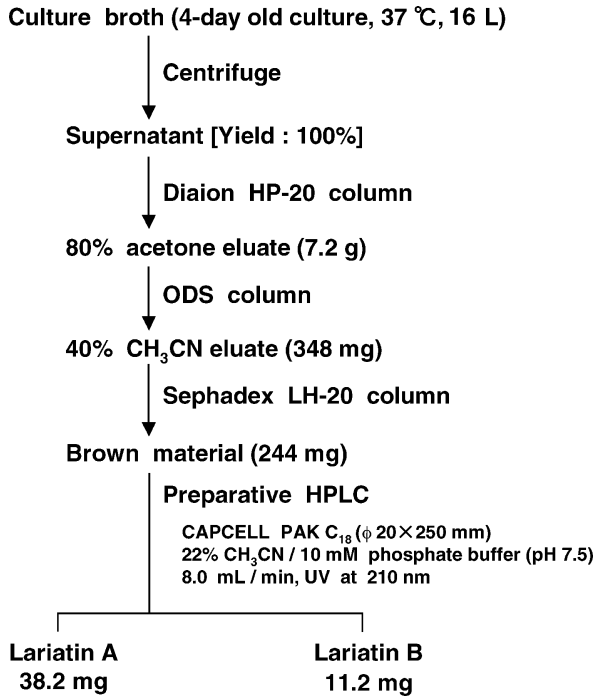

Scheme 1. Isolation procedures of lariatins A and B.

\section{Isolation}

The procedure for the isolation of lariatins $\mathrm{A}$ and $\mathrm{B}$ is summerized in Scheme 1. The 4-day old culture broth (16 liters) was centrifuged to separate mycelium and supernatant. The supernatant was passed through a column of Diaion HP-20 $(75 \times 220 \mathrm{~mm}$, Nihon Rensui Co. $)$ 
previously equilibrated with water. After washing with water (3 liters) and $20 \%$ acetone ( 3 liters), the active materials were eluted with $80 \%$ acetone ( 3 liters). The whole eluate was concentrated in vacuo and lyophilized to dryness to yield a brown material $(7.2 \mathrm{~g})$. The material was dissolved in water and applied on an ODS column $(35 \times 270 \mathrm{~mm}$, Senshu Scientific Co. $)$ previously equilibrated with water. After washing with water $(600 \mathrm{ml})$ and $20 \%$ acetonitrile $(600 \mathrm{ml})$, the active materials were eluted with $40 \%$ acetonitrile $(600 \mathrm{ml})$. The whole eluate was concentrated in vacuo to dryness to yield a brown material $(348 \mathrm{mg})$. The material was dissolved in a small amount of methanol and passed through a Sephadex LH-20 column $(25 \times 1100 \mathrm{~mm}$, Amersham Biosciences Co. $)$. The active fractions were concentrated in vacuo to dryness to yield a brown material $(244 \mathrm{mg})$. The active material was purified by HPLC on a CAPCELL PAK $\mathrm{C}_{18}$ column (20 i.d. $\times 250 \mathrm{~mm}$, Shiseido Co.) with $22 \%$ acetonitrile containing $10 \mathrm{mM}$ phosphate buffer $(\mathrm{pH} 7.5)$ at $8 \mathrm{ml} /$ minute detected at UV $210 \mathrm{~nm}$. The retention times of lariatins $\mathrm{A}$ and $\mathrm{B}$ were 44 and 56 minutes, respectively (Fig. 6). The active fractions were desalted on an OASIS HLB column (60 mg, Waters Co.) previously equilibrated with water. After washing with water $(3 \mathrm{ml})$, lariatins were recovered with $80 \%$ acetonitrile $(2 \mathrm{ml})$, each of which was concentrated in vacuo to dryness to afford lariatin A (38.2 mg) and lariatin B (11.2 mg) as pale yellow powders [6].

\section{Physico-chemical Properties}

The physico-chemical properties of lariatins A and B are summarized in Table 1. Lariatins $\mathrm{A}$ and $\mathrm{B}$ had molecular formula of $\mathrm{C}_{94} \mathrm{H}_{143} \mathrm{~N}_{27} \mathrm{O}_{25}$ and $\mathrm{C}_{101} \mathrm{H}_{153} \mathrm{~N}_{29} \mathrm{O}_{27}$ respectively, established on the basis of HRFAB-MS 2051.0764

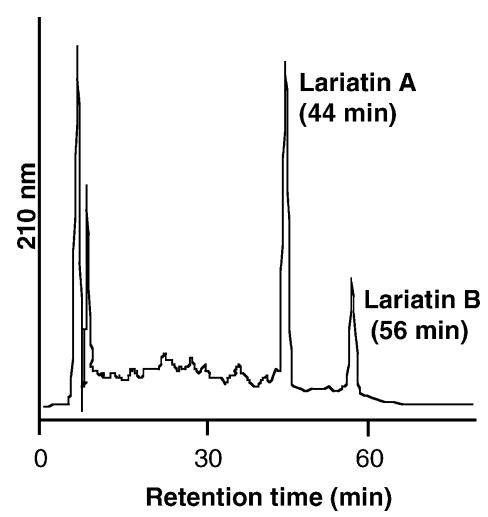

Fig. 6 Purification of lariatins A and B by HPLC.

The detail condition of HPLC was described in "Results".

Table 1 Physico-chemical properties of lariatins A and B

\begin{tabular}{|c|c|c|}
\hline & Lariatin A & Lariatin B \\
\hline Appearance & Pale yellow powder & Pale yellow powder \\
\hline Molecular formula & $\mathrm{C}_{94} \mathrm{H}_{143} \mathrm{~N}_{27} \mathrm{O}_{25}$ & $\mathrm{C}_{101} \mathrm{H}_{153} \mathrm{~N}_{29} \mathrm{O}_{27}$ \\
\hline Molecular weight & 2050 & 2204 \\
\hline \multicolumn{3}{|l|}{ FAB-MS $(m / z)$} \\
\hline \multirow[t]{2}{*}{ positive } & $2051[\mathrm{M}+\mathrm{H}]^{+}$ & $2205[\mathrm{M}+\mathrm{H}]^{+}$ \\
\hline & $2073[\mathrm{M}+\mathrm{Na}]^{+}$ & \\
\hline \multicolumn{3}{|l|}{ HRFAB-MS (m/z) } \\
\hline calcd. & 2051.0826 & 2205.1568 \\
\hline found $[\mathrm{M}+\mathrm{H}]^{+}$ & 2051.0764 & 2205.1504 \\
\hline$[\alpha]_{D}^{26}(c 0.3,50 \% \mathrm{MeOH})$ & $-19.6^{\circ}$ & $-26.6^{\circ}$ \\
\hline \multirow[t]{3}{*}{$U V \lambda_{\max }^{50 \% \mathrm{MeOH}} \mathrm{nm}(\varepsilon)$} & $203(182,700)$ & $203(225,200)$ \\
\hline & $220(66,800)$ & $220(83,200)$ \\
\hline & $284(9,800)$ & $284(11,900)$ \\
\hline $\mathrm{IR} v_{\max }^{\mathrm{KBr}} \mathrm{cm}^{-1}$ & 1650 & 1643 \\
\hline Melting point & $240^{\circ} \mathrm{C}$ (dec) & $240^{\circ} \mathrm{C}$ (dec) \\
\hline \multicolumn{3}{|l|}{ Solubility } \\
\hline soluble & $\mathrm{H}_{2} \mathrm{O}, \mathrm{MeOH}, \mathrm{DMSO}$ & $\mathrm{H}_{2} \mathrm{O}, \mathrm{MeOH}, \mathrm{DMSO}$ \\
\hline insoluble & $\mathrm{CHCl}_{3}, \mathrm{EtOAC}$ & $\mathrm{CHCl}_{3}, \mathrm{EtOAc}$ \\
\hline \multicolumn{3}{|l|}{ Color reaction } \\
\hline \multirow[t]{2}{*}{ positive } & Ninhydrin & Ninhydrin \\
\hline & Rydon-Smith & Rydon-Smith \\
\hline
\end{tabular}


Table 2 Antimicrobial activity of lariatins A and B

\begin{tabular}{|c|c|c|c|}
\hline \multirow{2}{*}{ Test organism } & \multicolumn{3}{|c|}{ Inhibition zone $(\mathrm{mm})$ at $10 \mu \mathrm{g} / 6 \mathrm{~mm}$ disk } \\
\hline & Lariatin A & Lariatin B & Isoniazid \\
\hline Bacillus subtilis ATCC6633 & - & - & - \\
\hline Staphylococcus aureus ATCC6538P & - & - & - \\
\hline Micrococcus luteus ATCC9341 & - & - & - \\
\hline Mycobacterium smegmatis ATCC607 & 19 & 18 & 26 \\
\hline Escherichia coli NIHJ & - & - & - \\
\hline Pseudomonas aeruginosa IFO3080 & - & - & - \\
\hline Xanthomonas campestris KB88 & - & - & - \\
\hline Bacteroides fragilis ATCC23745 & - & - & - \\
\hline Acholeplasma laidlawii KB174 & - & - & - \\
\hline Pyricularia oryzae KB180 & - & - & - \\
\hline Aspergillus niger ATCC9642 & - & - & - \\
\hline Mucor racemosus IFO4581 & - & - & - \\
\hline Candida albicans ATCC64548 & - & - & - \\
\hline Saccharomyces cerevisiae KF26 & - & - & - \\
\hline
\end{tabular}

$[\mathrm{M}+\mathrm{H}]^{+}$(calcd. 2051.0826) and 2205.1504 [M+H] (calcd. 2205.1568). It was supported by NMR analysis (date not shown). Rydon-Smith reaction was positive and the absorption at $1650 \mathrm{~cm}^{-1}$ was dominant in the IR spectra, indicating that these compounds are peptides. From these date, lariatins are found to be novel compounds. The structures were elucidated as shown in Fig. 1, which was published elsewhere [6].

\section{Biological Activities}

Lariatins A and B showed strong inhibition only against $M$. smegmatis among 14 microorganisms tested as well as isoniazid on the conventional paper disk assay (Table 2). Therefore, anti-mycobacterial activity using an agar dilution method was studied. The MIC values of lariatins A and B were 3.13 and $6.25 \mu \mathrm{g} / \mathrm{ml}$ for $M$. smegmatis Takeo, respectively. Furthermore, in liquid microdilution method, lariatin A inhibited the growth of M. tuberculosis with an MIC value of $0.39 \mu \mathrm{g} / \mathrm{ml}$.

\section{Discussion}

Mycobacteria have a very unique cell wall structure. From the whole genome sequence [25], there are a number of enzymes involved in biosynthesis of the cell wall. For example, mycolic acids, extremely long fatty acids, form a broad family of more than 500 closely related structures and comprise about $30 \%$ of the dry weight of $M$. tuberculosis, and the microorganism has about 250 distinct enzymes involved in fatty acid metabolism (vs. 50 for $E$. coli). Isoniazid and ethambutol are first line tuberculosis drug, which inhibit cell wall biosynthesis; isoniazid inhibits mycolic acid synthesis by blockade of Type II fatty acid synthase [26], and ethambutol inhibits arabinogalactan mycolate synthesis by blockade of arabinosyltransferase [27]. Recently, platensimycin with a very unique structure was isolated as an inhibitor of Fab2 in Type II fatty acid synthase from Streptomyces starin [28]. Interestingly, lariatins show specific inhibition against mycobacterial growth. As described above, the compounds show the similar biological characteristics. They inhibited the growth of not only M. smegmatis but also M. tuberculosis (Table 2). Therefore, it might be plausible that the target molecule of lariatins lies within the cell wall biosynthetic steps in mycobacteria as well as isoniazid and ethambutol.

Acknowledgments This study was supported in part by the grant of the 21st Century COE Program and Scientific Research on Priority Areas 16073215 from the Ministry of Education, Culture, Sports, Science and Technology, Japan. We thank to Ms. Miki Teshima, Microbiological Research Institute Otsuka Pharmaceutical Co., Ltd., for her useful advice and the measurement of MICs.

\section{References}

1. Fukuda T, Matsumoto A, Takahashi Y, Tomoda H, Ōmura S. Phenatic acids $\mathrm{A}$ and $\mathrm{B}$, new potentiators of antifungal miconazole activity produced by Streptomyces sp. K03- 
0132. J Antibiot 58: 252-259 (2005)

2. Fukuda T, Arai M, Tomoda H, Ōmura S. New beauvericins, potentiators of antifungal miconazole activity, produced by Beuberia sp. FKI-1336. J Antibiot 57: 117-124 (2004)

3. Kim YP, Tomoda H, Iizima K, Fukuda T, Matsumoto A, Takahashi Y, Ōmura S. Takanawaeness, novel antifungal antibiotics produced by Streptomyces sp. K99-5278. J Antibiot 56: 448-453 (2003)

4. NIAID's Tuberculosis Antimicrobial Acquisition \& Coordinating Facility (TAACF). web site: http://www. Taacf.org/about-TB-background.html (accessed May 1, 2005).

5. O'Brien RJ. Global alliance for TB drug development. Scientific blueprint for TB drug development. Tuberculosis 81: 1-52 (2001)

6. Iwatsuki M, Tomoda H, Uchida R, Gouda H, Hirono S, Ōmura S. Lariatins, antimycobacterial peptides produced by Rhodococcus sp. K01-B0171, have a lasso structure. J Am Chem Soc 128: 7486-7491 (2006)

7. Matsumoto A, Takahashi Y, Iwai Y, Ōmura S. Isolation of gram-positive bacteria with high $\mathrm{G}+\mathrm{C}$ from inside soil aggregates. Actinomycetol 20: 30-34 (2006)

8. Shirling EB, Gottlieb D. Methods for characterization of Streptomyces species. Int J Syst Bacteriol 16: 313-340 (1966)

9. Waksman SA. (Ed.) Classification, identification and description of genera and species. The actinomycetes. Vol. 2, Williams and Wilkins Co. (1961)

10. Pridham TG, Gottlieb D. The utilization of carbon compounds by some Actinomycetales as an aid for species determination. J Bacteriol 56: 107-114 (1948)

11. Becker B, Lechvalier MP, Lechvalier HA. Chemical composition of cell-wall preparation from strains of various form-genera of aerobic actinomycetes. Appl Microbiol 13: 236-243 (1965)

12. Hasegawa T, Takizawa M, Tanida S. A rapid analysis for chemical grouping of aerobic actinomycetes. J Gen Appl Microbiol 29: 319-322 (1983)

13. Uchida K, Aida K. Acyl type of bacterial cell wall: Its simple identification by colorimetric method. J Gen Appl Microbiol 23: 249-260 (1977)

14. Tomiyasu I. Mycolic acid composition and thermally adaptative changes in Nocardia asteroides. J Bacteriol 151: 828-837 (1982)

15. Minnikin DE, Patel PV, Alshamaony L, Goodfellow M. Polar lipid composition in the classification of Nocardia and related bacteria. Int J Syst Bacteriol 27: 104-117 (1977)

16. Collins MD, Goodfellow M, Minnikin DE. Distribution of menaquinones in actinomycetes and corynebacteria. J Gen Microbiol 100: 221-230 (1977)

17. Tamaoka J, Katayama FK, Kuraishi H. Analysis of bacterial menaquinone mixtures by high performance liquid chromatography. J Appl Bacteriol 54: 31-36 (1983)
18. Tamaoka J, Komagata K. Determination of DNA base composition by reversed-phase high-performance liquid chromatography. FEMS Microbiol Lett 25: 125-128 (1984)

19. Thompson JD, Higgins DG, Gibson TJ. CLUSTAL W: improving the sensitivity of progressive multiple sequence aligmnent through sequence weighting, position specific gap penalties and weight matrix choice. Nucleic Acids Res 22: 4673-4680 (1994)

20. Kimura M. A simple method for estimating evolutionary rates of base substitutions through comparative studies of nucleotide sequence. J Mol Evol 16: 111-120 (1980)

21. Saitou N, Nei M. The neighbor-jointing method: a new method for reconstructing phylogenetic trees. Mol Biol Evol 4: 406-425 (1987)

22. Zhang H, Tomoda H, Tabata N, Oohori M, Shinose M, Takahashi Y, Ōmura S. Zelkovamycin, a new cyclic peptide antibiotic from Streptomyces sp. K96-0670 1. Production, isolation and biological properties. J Antibiot 52: 29-33 (1999)

23. Josef FH, Venet MG, Herve JJ, Laurence FB, Vernier DF. Quinoline derivatives and their use as mycobacterial inhibitors. PCT/EP2003/050322 (2003)

24. Takeuchi M, Hatano K, Sedolàcek IZ, Pàcovà IZ. Rhodococcus jostii sp. nov., isolated from a medieval grave. Int J Syst Evol Microbiol 52: 409-413 (2002)

25. Cole ST, Brosch R, Parkhill J, Garnier T, Churcher C, Harris D, Gordon SV, Eiglmeier K, Gas S, Barry CE 3rd, Tekaia F, Badcock K, Basham D, Brown D, Chillingworth T, Connor R, Davies R, Devlin K, Feltwell T, Gentles S, Hamlin N, Holroyd S, Hornsby T, Jagels K, Krogh A, McLean J, Moule S, Murphy L, Oliver K, Osborne J, Quail MA, Rajandream MA, Rogers J, Rutter S, Seeger K, Skelton J, Squares R, Squares S, Sulston JE, Taylor K, Whitehead S, Barrell BG. Deciphering the biology of Mycobacterium tuberculosis from the complete genome sequence. Nature 6685: 515-516 (1998)

26. Siayden RA, Lee RE, Barry CE 3rd. Isoniazid affects multiple components of the type II fatty acid synthase system of Mycobacterium tuberculosis. Mol Microbial 38: 514-525 (2000)

27. Takayama K, Datte AK. Structure-to-function relationship of mycobacterial cell envelope components. Res Microbiol 142: 443-448 (1991)

28. Wang J, Soisson SM, Young K, Shoop W, Kodali S, Galgoci A, Painter R, Parthasarathy G, Tang YS, Cummings R, Ha S, Dorso K, Motyl M, Jayasuriya H, Ondeyka J, Herath K, Zhang C, Hernandez L, Allocco J, Basilio A, Tormo JR, Genilloud O, Vicente F, Pelaez F, Colwell L, Lee SH, Michael B, Felcetto T, Gill C, Silver LL, Hermes JD, Bartizal K, Barrett J, Schmatz D, Becker JW, Cully D, Singh SB. Platensimycin is a selective FabF inhibitor with potent antibiotic properties. Nature 7091: 358-361 (2006) 